\title{
ARISTOTLE'S POETICS: A TOPICAL APPROACH
}

\begin{abstract}
Summary: Character, meaning a full personality, seems to be naturally connected to action in modern thought. In contrast, Aristotle dissociates these concepts inasmuch that he accepts the possibility of action without character, as well as texts representing character without action. Action and character can nonetheless be linked through the concept of proairesis, a concept that is also useful for clarifying the possibility of a tragedy without character, in spite of the fundamental connection between action and character. At the end of the paper the modern concept of ordeal is also discussed since this concept appears to be a useful general approach and one also related to Aristotle's concept of proairesis.
\end{abstract}

Key words: Aristotle, Poetics, proairesis, tragedy.

Aristotle's Poetics has a special prestige in modern European literary thought and therefore some of the statements contained therein and its general attitude may seem topical in one way or another. Still, we cannot be certain of this topicality in the sense that a thorough analysis reveals that many of the concepts in the Poetics that are familiar from contemporary literary thought can be seen to refer to different concepts and an attitude differing from our own. Topicality usually means that we use an approach from the past to shed new light on problems cardinal to present thought. Be as it may, we can find no better way of understanding Aristotle's text than by comparing it with modern attitudes to literature.

Any concept in the Poetics can be chosen for such a comparison. In this paper I will focus on the concept of character or, better said, on the views contained in Chapter 6 of the Poetics on character. In our modern approach to literature, character has attained a central position, the most important reason for this being that the novel - the most prestigious genre of modern European literature - has developed highly sophisticated techniques for representing characters. Since the mid-19th century, character has become the central feature (or at least one of the central features) of the novel and of the strategies of reading novels. I would emphasize two points. First, our own understanding of literature is, for the greater part, based on the 19 th century novel or, to be more precise, on 19th century strategies of reading 19th century novels. This must always be borne in mind when discussing ancient drama or the ancient theory of drama, even though the critical system in which these reading strategies 
evolved are said to be based on the dramatic genre. ${ }^{1}$ Second, the word, $\tilde{\eta} \theta$ os, usually translated as 'character', has a completely different meaning in Aristotle's Poetics than the modern scholarly usage. ${ }^{2}$

To the modern attitude, character means a full personality and seems to be naturally connected with action. We cannot help but remember Henry James' words from The Art of Fiction: "What is character but the determination of incident? What is incident but the illustration of character?"3 We feel uncomfortable with the fact that Aristotle dissociates these features: ${ }^{4}$ he finds both action without character and

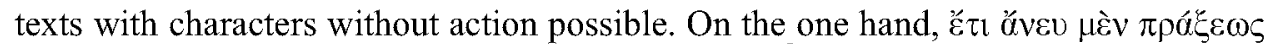

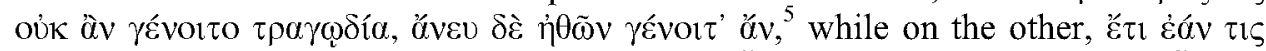

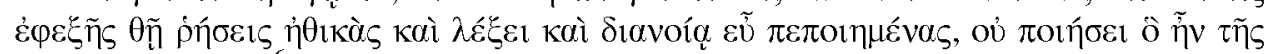

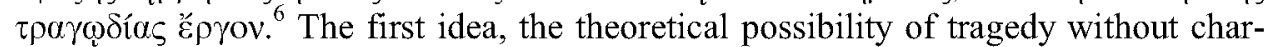
acter seemed so striking that some commentators tried to interpret the phrase óvev

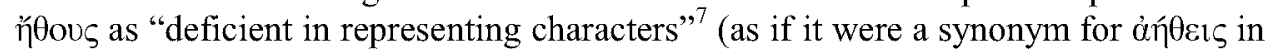
the next line). Their argument was very simple and based on a previous statement in Chapter 6 of the Poetics: tragedy is the imitation of action, while action is performed

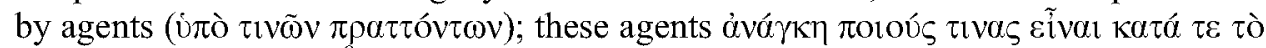

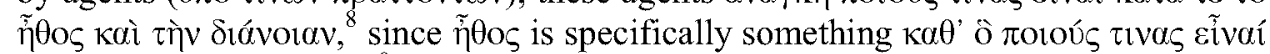

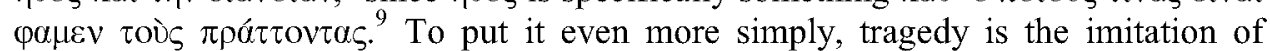
action, action is performed by agents who, according to Aristotle, "necessarily" have some qualities that they cannot be said to do but on the basis of their $\check{\eta} \theta \eta$; in consequence, there must be $\tilde{\eta} 00 \mathrm{~s}$ in every tragedy. ${ }^{10}$ In this case, the expression "tragedy without character" can hardly mean a tragedy without character since this is impossible.

This argument is evidently based on the modern preoccupation with a strict relation between action and character that the above quoted sentences apparently deny; it makes the need for character follow from the action. However, this approach cannot be maintained: although Aristotle considers a tragedy without character possible, 349-353.

${ }^{1}$ Miner, E.: On the Genesis and Development of Literary Systems. Critical Inquiry 5, 1978,

${ }^{2}$ Halliwell, S.: Aristotle's Poetics. London 1986, 150, 162.

${ }^{3}$ Quoted from The Art of Criticism: Henry James on the Theory and Practice of Fiction. Edited by W. VEEDER and S. M. GRIFFIN. Chicago-London 1986, 174. It is important for the character-centred attitude of modern prose reading strategies that James' quoted passage was interpreted as declaring the primacy of the character. Cp. TODOROV, T.: Narrative men. In: The Poetics of Prose. Translated by R. Howard. Oxford 1971, 66.

${ }_{4}^{4}$ According to HALliwELl, op. cit. (note 2), 149, it is the unfamiliar nature of this disjunction that causes the problems in understanding the statements of the Poetics concerning our topic.

${ }^{5}$ 1450a23-25: "without action a tragedy cannot exist, but without characters it may." In the following I shall quote R. JANKO's translation (Aristotle, Poetics. Indianapolis-Cambridge 1987).

${ }^{6}$ 1450a29-31: "if a poet puts in a sequence speeches full of character, well-composed in diction and reasoning, he will not achieve what was agreed to be the function of tragedy."

${ }^{7}$ BYWATER, I.: Aristotle and the Art of Poetry. Oxford 1909.

${ }^{8} 1449$ b36-38: "are necessarily of a certain sort according to their character and their reasoning."

${ }^{9} 1450$ a 5-6: "according to which we say that people are of a certain sort."

${ }^{10}$ This is LUCAS' argument in his Aristotle Poetics. Oxford 1968, ad 1450a24. This argument is rejected by JANKO, op . cit. (note 5), ad 1450a24. 
he does not regard this as desirable. ${ }^{11}$ As for the previous statement - namely, that agents necessarily have qualities - the attempts to reconcile the apparently different usage of the same term in different passages of the Poetics play an important role in the history of interpretation. In spite of the many ingenious attempts, the outcome is rarely satisfactory. Such an apparent inconsistency can easily be the result of a different point of view. Regarding the relation between muthos, ethos and dianoia, these concepts appear to be 'necessarily' related. However, a change of perspective and a new subject, the primary importance of muthos in comparison with the other concepts, results in that the three concepts can suddenly become unrelated to each other. In an extreme case of interpretation, in one that adheres too closely to the literal meaning, the expression ethos may have a different meaning within the same sentence. It has been suggested that this expression can hardly have the same meaning in the

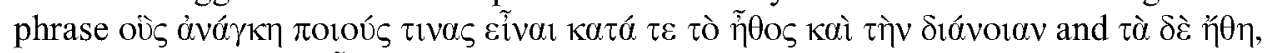

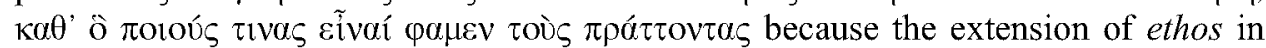
the second phrase is synonymous with the extension that ethos and dianoia together have in the first one. ${ }^{12}$ To me, this seems a little like splitting hairs. Still, this example is suitable for drawing attention to the fact that caution must be exercised in reconciling passages that explain the same concepts from different perspectives.

According to Else, the word $\varphi$ á $\mu \varepsilon v$, 'we say', may provide the solution: one who acts, no matter what, necessarily has certain qualities in real life, whereas in a play we can only judge him by the signals placed in the text by the author. Thus, the word $\varphi \alpha \mu \varepsilon v$ relegates the matter of character in the audience's competence to some extent. But only to some extent - in contrast, Else believes that the process of assigning certain qualities to the agents is entirely determined by the text: by the acts and words of the agent. ${ }^{13}$ The beholder plays but a passive role of providing a point of view from where the signals creating the character can be seen. Thus a tragedy without a character simply appears as a tragedy that does not reveal or clarify the agents' qualities to the audience. (It must here be noted that Schütrumpf believes that the importance attached by Else to this one word is highly exaggerated since Aristotle simply uses passive structures in other passages. ${ }^{14}$ ) Be as it may, if the signals by which the author communicates character to the audience involve not only words, but acts as well, we may conclude that action without character is impossible. We can resolve this problem by assuming that not every act can be regarded as such a signal.

We may now widen the scope of our analysis to include a term, proairesis, that seems to be of cardinal importance for the relation between action and character. At

${ }^{11}$ HALLIWELL, op. cit. (note 2), 163.

${ }^{12}$ HeLd, G. F.: The meaning of $\eta^{*} \theta 0 \mathrm{~s}$ in the "Poetics". Hermes 113, 1985, 283-284. This seems unacceptable to me as a real possibility. The first part of the sentence is a statement on the relation between the three concepts, followed by a series of definitions of these concepts, offering a definiton of the exact meaning of these concepts. This logical sequence is indicated by the introductory $\lambda \dot{\varepsilon} \gamma \omega \delta \dot{\varepsilon}$. Such a definition can hardly imply a meaning different from the preceding statement.

${ }^{13}$ ELSE, G. F.: Aristotle's Poetics: The Argument. Leiden 1957, 242.

${ }^{14}$ Schütrumpr, E.: Die Bedeutung des Wortes $\tilde{\hat{n}} \theta$ os in der Poetik des Aristoteles. Zetemata 49. München 1970, 89-90. 


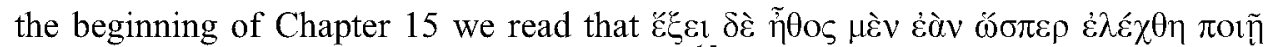

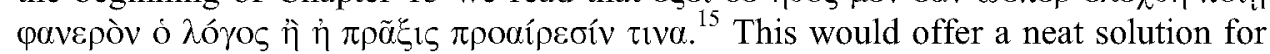
the problem of tragedy without character. If there is no choice, or at least no apparent choice, there can hardly be a character. Thus, it does not follow that we can judge the character from an action, only from actions of a certain type or from speeches displaying the process of choice that result in action.

Although the previous argument might suggest that my interpretation of Chapter 6 is based on passages in Chapter 15, this is not really the case: the term proaire-

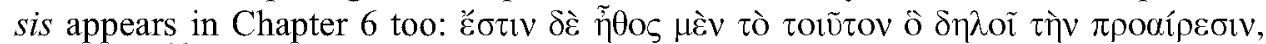
ómoía $\tau 1 \zeta .{ }^{16} \mathrm{I}$ have quoted this passage from Chapter 15 because it refers to the function of action as signals of characters, whereas in Chapter 6 only speech is accorded this role. A degree of inconsistency may be seen between these passages: the question arises as to what is made obvious by what? In Chapter 6 it is ethos that

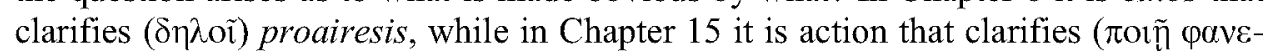
pòv) prohairesis that makes the agent have character, suggesting that it is proairesis that clarifies character. Some commentators resolve this problem by inverting the subject-object relation in Chapter $6 .{ }^{17}$ This approach is supported to some extent by the Nicomachean Ethics in which proairesis also plays a central role: $\pi \varepsilon \rho i$

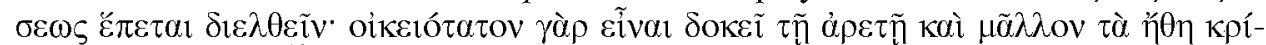
v๕ıv $\tau \tilde{\omega} v \pi \rho a ́ \xi \varepsilon \omega v .{ }^{18} \mathrm{I}$ am inclined to regard this inconsistency as a mere guise: on the one hand, the only explanation for one's choice in a given situation is one's character, while on the other, if one wants to judge another's character from an outsider position, so to say, one can only do so by this very choice.

In any case, we have now managed to link action and character through the concept of proairesis. ${ }^{19}$ This link, however, leads to other problems. This concept can offer an explanation for the possibility of tragedy without character, in spite of the essential connection between action and character. It is most satisfactory that this explanation corresponds to the usage of Aristotle in his ethics. Still, this close connection challenges the theoretical possibility of inserting speeches, representing character, one after the other, without creating a muthos, a plot. Even more so, since a speech containing character concerns a choice, especially a choice manifested in an action. ${ }^{20}$ We should perhaps imagine a kind of text in which certain persons appear, explain the motivation of their choices in speeches and then do nothing. ${ }^{21}$ But without action, how can any person find himself in a situation in which he is compelled to make a choice? Should we regard a decision that will not be acted upon as a choice?

\footnotetext{
${ }^{15}$ 1454a17-18: "The tragedy will have character if the speech or the action makes obvious a decision of whatever sort."

${ }^{16} 1450 \mathrm{~b} 8-10$ : "Character is which reveals decision, of whatever sort."

${ }^{17}$ For example LUCAS, op. cit. (note 10), ad $1450 \mathrm{~b} 8$.

${ }^{18} 1111$ b5-6: "We must next discuss choice; for it is thought to be most closely bound up with virtue and to discriminate characters better than actions do." Translation by J. L. ACKRILL: Aristotle's Ethics. London 1973.

${ }^{19} \mathrm{Cp}$. Halliwell, op. cit. (note 2), 156.

${ }^{20} \mathrm{Cp}$. the close link between ethos and praxis in Aristotle's Ethics.

${ }^{21}$ REES, B. R.: Plot, Character and Thought. In: Le Monde grec: Hommage à Claire Préaux. Bruxelles 1975, 194.
} 
We might find a solution in the word ephexes, one after the other. Aristotle notes that a mere series of such speeches will not constitute a tragedy since it will lack muthos that is regarded as sustasis pragmatōn. ${ }^{22}$ But how should we conceive a series of texts in which actions reflecting character follow each other without any connection whatsoever? This is a difficult question and in my opinion Aristotle is probably correct in suggesting that such texts can hardly fulfil the function of a tragedy.

We also have to examine another problem. How can the cardinal importance of choice in a tragedy (or at least in a tragedy containing character) be reconciled with the requirement of a unique plot that calls for a sequence of events that follow each other by necessity or probability? The solution to the problem of character was in part based on Aristotle's Ethics - although based on this we would have to deny that necessity plays any role in human action. ${ }^{23}$ Aristotle appears to have presented us with two incompatible preferences: in one passage he approves of tragedies in which every event is determined by necessity and choice does not play an important role, while in another he declares that tragedies without character are inferior.

It is clear, however, that the concept of praxis as the uniform plot of a tragedy, meaning a unique causal sequence of events, can hardly be reconciled with the agents' freedom of choice, a precondition to their having a character. This contradiction can be resolved if one tragedy only has one character, that of the protagonist who at the beginning of the play makes one single decision and all ensuing events are the consequence of this decision. ${ }^{24}$ For my part, I would prefer more than one character and more than a single situation demanding that a choice be made during the plot. Taken in this sense, the concept of proairesis is more familiar not only because of the link it forges between action and character, but also because of its close relation to the modern concept of ordeal.

Ordeal plays a role in Propp's Morphology of the Folktale, even if this role is somewhat subordinate. On the one hand, the hero is first tried as a donor in order to receive a magical agent or helper, while on the other, when everything seems to turn out all right at the end, but a false hero appears to present his unfounded claims, a rather difficult ordeal must be undergone by the real hero in order to prove his identity. ${ }^{25}$ In his reworking of Propp's model, Greimas attributed a cardinal importance to the ordeal since he regarded the middle part of folktales as a series of tests. ${ }^{26}$ The hero's actions during these ordeals are free, and they are also characterized by choice and irreversibility - both elements that determine the historical activity of humankind. ${ }^{27}$ However, unlike Aristotle's concept of proairesis, these statements do not reveal how the ordeal links character and action. The solution is provided by Bakhtin's

${ }^{22}$ VAHLEN, I.: Aristoteles' Lehre von der Rangfolge der Teile der Tragoedie. In: Symbola philologorum Bonnensium in honorem Friderici Ritschelii collecta. Lipsiae 1864, 163 = VAHLEN: Gesammelte philologische Schriften I. Leipzig-Berlin 1911, 243, Anm. ad 13; cp. also ELSE, op. cit., (note 13), 259.

${ }_{3}$ HALLIWELL, op. cit. (note 2), 99 ff., esp. 106.

${ }^{24}$ RiToóK, ZS.: Zur mimesis praxeos. Acta Ant. Hung. 38, 1998, 237.

${ }^{25}$ Propp, V.: Morphology of the Folktale. Transl. by L. Scott. 2 nd edition, revised by L. A. Wagner. Austin, Texas, 1968, 39-42 and 60-62.

${ }^{26}$ MÉLÉTINSKI, E.: L'étude structurale et typologie du conte. Transl. by Claude Kahn. In PROPP, op. cit. (note 25), 223.

${ }^{27}$ MÉLÉTINSKI, op. cit. (note 26), 226-227. 
view on the novel of ordeal that "is constructed as a series of tests of the main heroes, tests of their fidelity, valor, bravery, virtue, nobility, sanctity and so on. This is the most widespread subcategory of the novel in European literature. It encompasses a considerable majority of all the novels produced. The world of this novel - the arena of struggle and testing of the hero; events and adventures - is a touchstone for the hero." ${ }^{28}$ This would suggest that the test is part of the action on the one hand, and that its function is to reveal the ethical qualities of the agent on the other. This phenomenon is obviously not restricted to the novel of ordeal alone - the novel type dominating European literature in Bakhtin's view - but can also appear in other novel types. This seems to be a highly general approach and closely allied to Aristotle's concept of proairesis.

The similarity between proairesis and ordeal supports our belief concerning the interrelation between character and action, even if this interrelation sometimes appears to be somewhat problematic in the Poetics. The concept of ordeal can be of help in understanding Aristotle's concept of proairesis, but we should be aware of the pitfalls of this interpretation since it strengthens our modern theories.

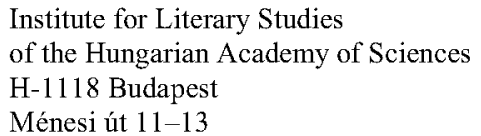

${ }^{28}$ BAKHTIN, M. M.: The Bildungsroman and its Significance in the History of Realism. In: Speech Genres \& Other Late Essays. Transl. by V. W. McGee. Austin 1986, 11-12. 